\title{
Pengetahuan Didaktika Calon Guru Sekolah Dasar tentang Pecahan Ditinjau dari Teori Antropologi Didaktik
}

\author{
Zetra Hainul Putra ${ }^{1^{*}}$, Gustimal Witri ${ }^{2}$, Intan Kartika Sari ${ }^{3}$ \\ ${ }^{1,2,3}$ Fakultas Keguruan dan Ilmu Pendidikan, Universitas Riau \\ *zetra.hainul.putra@lecturer.unri.ac.id
}

\begin{abstract}
Abstrak
Calon guru sekolah dasar dituntut memiliki pengetahuan matematika dan didaktika yang layak tentang pecahan, namun pada kenyataannya banyak dari mereka yang kesulitan dalam menjelaskan beragam konsep pecahanan kepada siswa. Mengingat pentingnya pengetahuan calon guru tentang pecahan maka penelitian ini bertujuan untuk menginvestigasi lebih lanjut tentang pengetahuan didaktika calon guru sekolah dasar tentang pecahan. Pengetahuan didaktika calon guru tersebut ditinjau dari kemampuan mereka mengkonstruksi soal-soal kontekstual tentang pecahan berdasarkan aspek number sense, pemecahan masalah, literasi matematika, dan problem posing. Pengetahuan didaktika tersebut kemudian di analisis berdasarkan teori antropologi didaktik. Metode penelitian yang digunakan yaitu kualitatif dengan pendekatan internet-based research. Subjek penelitian ini terdiri dari 38 mahasiswa semester 6 pendidikan guru sekolah dasar dari sebuah institusi pendidikan guru di Pekanbaru, Riau, Indonesia. Hasil studi ini menunjukkan bahwa pengetahuan didaktika calon guru sekolah dasar tentang pecahan masih rendah, terutama pada aspek mengkonstruksi soal kontekstual tentang pembagian pecahan dengan pecahan. Sementara itu, mereka cenderung menyajikan tipe soal terkait dengan operasi pecahan sederhana bersamaan dengan teknik berupa algoritma standar. Hasil studi ini juga mengindikasikan bahwa pengetahuan teoritis calon guru sekolah dasar masih terbatas pada pengetahuan informal untuk mendukung algoritma standar.
\end{abstract}

Kata kunci: pecahan, pengetahuan matematika, pengetahuan didaktika, teori antropologi didaktik

\begin{abstract}
Prospective elementary teachers (PET) are required to have sufficient mathematical and didactic knowledge about fractions, but many of them have difficulties explaining various concepts of fractions to students. Given the importance of prospective teachers' knowledge of fractions, this study aims to investigate further the didactic knowledge of PETs' didactic knowledge of fractions. Their knowledge is seen from their ability to construct contextual tasks about fractions based on number sense, problem-solving, mathematical literacy, and problem posing. PETs' didactical knowledge is analyzed based on the anthropological theory of the didactic. This research method is qualitative with an internet-based research approach. The subjects of this study consist of 38 PsETs from a teacher education institution in Pekanbaru, Riau, Indonesia. The results of this study indicate that PsETs' didactic knowledge of fractions is inappropriate, especially in the aspect of constructing contextual tasks about the division of fractions by fractions. PsETs tend to present the type of task associated with simple fraction operations and techniques in the form of standard algorithms. This study also indicates that PsETs' theoretical knowledge is still limited to informal knowledge to support standard algorithms.

Keywords: fractions, mathematical knowledge, didactical knowledge, anthropological theory of the didactic
\end{abstract}




\section{Pendahuluan}

Pecahan merupakan materi yang sulit bagi siswa untuk dipelajari, dan guru juga kesulitan dalam menjelaskan kepada siswa (Hill, Rowan, \& Ball, 2005; Siegler \& LortieForgues, 2017). Siswa kesulitan memahami pecahan karena sebelumnya di kelas rendah mereka memahami bilangan sebagai representasi dari objek konkret. Misalnya, angka 5 dipahami oleh siswa sebagai representasi dari 5 objek atau benda (Van Dooren, Lehtinen, \& Verschaffel, 2015). Sementara itu, pecahan, sebagaimana dijelaskan oleh Charalambous dan Pitta-Pantazi (2007), memiliki setidaknya lima subkonstruksi yaitu pecahan sebagai bagian dari keseluruhan, operator, hasil bagi, pengukuran dan rasio. Banyak guru berfokus pada penekanan konsep pecahan sebagai bagian dari keseluruhan (Durmus, 2005; Liu, Xin, \& Li, 2011; Putra, 2019a).

Rendahnya pengetahuan matematika siswa terutama tentang pecahan diyakini dipengaruhi oleh rendahnya pengetahuan matematika guru (Hill et al., 2005). Oleh karena itu, beragam studi tentang kemampuan matematika dan didaktika guru dan calon guru sekolah dasar tentang pecahan telah dilakukan baik skala internasional (Castro-Rodríguez, PittaPantazi, Rico, \& Gómez, 2016; Depaepe et al., 2015; Newton, 2008; Thanheiser, Moss, Browning, Garza-kling, \& Watanabe, 2010; van Steenbrugge, Lesage, Valcke, \& Desoete, 2014) maupun nasional (Johar, Patahuddin, \& Widjaja, 2017; Putra, 2016; Widjaja, Stacey, \& Steinle, 2008). Hasil studi tersebut menunjukkan beberapa kesamaan terutama terkait pengetahuan matematika dan didaktika guru dan calon guru masih rendah tentang pecahan dan operasinya. Sebagai contoh Putra (2016) menemukan bahwa hanya 44,53\% calon guru sekolah dasar yang sukses merepresentasikan operasi perkalian pecahan, dan $24,22 \%$ untuk pembagian pecahan. Mereka sangat kesulitan dalam merepresentasikan perkalian dan pembagian pecahan kedalam model persegi panjang. Padahal, kemampuan ini diperlukan guru dalam mengajarkan pemahaman operasi pecahan kepada siswa (Putra, 2016). Hasil yang sama juga ditemukan ketika beberapa calon guru sekolah dasar mendiskusikan bagaimana cara mengajarkan bilangan rasional ke siswa sekolah dasar (Putra, 2018). Pada umumnya mereka fokus bagaimana mengajarkan teknik atau prosedur standar ke siswa sekolah dasar tanpa menjelaskan konsep atau makna di balik prosedur tersebut sehingga ketika mereka lupa dengan teknik atau formula matematika, maka mereka tidak dapat menyelesaikan soal matematika yang ada dan menjelaskan ke siswa. Sehingga hal ini menunjukkan bahwa calon guru dan guru perlu mengembangkan pengetahuan dan keterampilan mereka tentang pecahan dan operasinya sebagai bentuk profesionalisme mereka dalam pembelajaran, 
Walaupun banyak studi terdahulu telah menginvestigasi pengetahuan calon guru dan guru tentang pecahan (Depaepe et al., 2015; Newton, 2008; van Steenbrugge et al., 2014), namun kecenderungan penelitian tersebut fokus pada evaluasi pengetahuan guru melalui tes dengan berfokus pada jawaban singkat yang diberikan oleh mereka. Hal ini tentu saja belum mengungkap sejauh mana pengetahuan guru terutama terkait dengan pengetahuan didaktika mereka yang berkaitan dengan pemilihan situasi ataupun soal yang akan diberikan ke siswa, apa strategi atau teknik yang akan muncul di kegiatan pembelajaran, serta penalaran dan teori matematis untuk menjustifikasi teknik-teknik yang dipilih dalam pembelajaran tersebut. Sebagaimana Chevallard (2006) mengungkapkan bahwa matematika merupakan aktivitas manusia, termasuk dalam hal ini pengetahuan calon guru, yang memuat dua komponen utama yaitu komponen praktis dan komponen teoritis, namun banyak dari studi-studi sebelumnya memfokuskan pada komponen praktis saja. Oleh karena itu, penelitian ini bertujuan untuk mengungkapkan bagaimana pengetahuan praktis calon guru sekolah dasar tentang pecahan, dan bagaimana pengetahuan praktis tersebut didukung oleh pengetahuan teoritis mereka. Sehingga, pengetahuan tersebut digunakan dalam membangung pengetahuan didaktis dalam pengajaran pecahan ke pada siswa sekolah dasar.

Pengetahuan calon guru maupun guru dapat digambarkan atas tiga komponen utama yaitu pengetauan konten, pengetahuan pedagogi, dan pengetahuan didaktika (DurrandGuerrier, Winsløw, \& Yoshida, 2010; Winsløw \& Durand-Guerrier, 2007). Pengetahuan konten diartikan sebagai pengetahuan guru terkait dengan prosedur, konsep, dan teori matematika. Pengetahuan pedagogi terkait dengan kemampuan guru secara umum dalam mengelola kelas dan pembelajaran. Sedangkan pengetahuan didaktika berkaitan dengan kondisi dan mekanisme pembelajaran matematika yang mensyaratkan penggunaan pengetahuan matematika guru dalam mengajar. Sementara itu banyak penelitian-penelitian yang berkiblat pada penelitian Anglo-Saxon, yang juga mempengaruhi penelitian di Indonesia, menggunakan istilah pengetahuan konten pedagogik untuk menggambarkan pengetahuan guru mengajar suatu konten misalnya matematika (Ball, Thames, \& Phelps, 2008). Namun dalam penelitian ini, peneliti menggunakan istilah pengetahuan didaktika, dimana pengetahuan matematika terkait dengan kemampuan calon guru atau guru menggunakan prosedur dan teori dalam menyelesaikan permasalahan matematika. Sedangkan pengetahuan didaktika berhubungan dengan bagaimana mereka dapat menggunakan pengetahuan matematika mereka dalam pembelajaran dan pengajaran matematikan ke siswa.

Untuk memodelkan dan menganalisa pengetahuan matematika dan didaktika calon guru, Chevallard (2006) dengan teori antropologi didaktikanya mengusulkan sebuah 
epistemologi model yang dikenal dengan istilah praxeology. Pengetahuan matematika dan didaktika calon guru atau guru dapat digambarkan dengan konsep praxeology yaitu yang terdiri dari dua komponen: praxis (blok praktikal) dan logos (blok teoretikal) (Bosch \& Gascón, 2006; Rasmussen, 2016; Wijayanti \& Winsløw, 2017). Sebuah blok praktis memuat dua komponen yaitu a type of task atau masalah yang ingin diselesaikan dan techniques atau beberapa teknik untuk menyelesaikan masalah tersebut. Jadi, ketika membicarakan pengetahuan matematika dan didaktika guru, maka tidak terlepas dari kemampuan guru menyelesaikan masalah matematika dan beragam teknik yang diperlukan untuk menyelesaikan masalah tersebut. Sebagai contoh, soal matematika tentang pecahan seperti bagaiaman menjumlahkan 2 pecahan, maka salah satu teknik yang harus dikuasai guru yaitu merubah kedua pecahan tersebut kedalam pecahan berpenyebut sama dan kemudian menjumlahkan pembilangnya. Bagian kedua, blok teori, juga dibentuk oleh 2 komponen yaitu technology (teknologi) dan theory (teori). Teknologi disini diartikan sebagai argumentasi atau penjelesan terhadap teknik yang digunakan, sedangkan teori merupakan konsep yang berlaku umum di matematika untuk menjustifikasi beragam teknologi. Kembali kecontoh penjumlahan pecahan, maka salah satu alasan kenapa perlu menyamakan penyebut yaitu dua pecahan dapat dijumlahkan apabila memiliki unit yang sama, dan konsep pecahan ekuivalen atau senilai dapat digunakan untuk menjastifikasi teknologi yang digunakan. Sehingga empat komponen, soal, teknik, teknologi, dan teori, merupakan komponen yang dapat digunakan untuk mempelajari pengetahuan guru. Jadi, dalam penelitian ini, peneliti menggunakan praxeology sebagai model untuk menganalisa pengetahuan calon guru sekolah dasar, khususnya pengetahuan didaktika mereka.

\section{Metode}

Metode penelitian secara umum merupakan penelitian kualitatif dengan pendekatan internet-based research (Cohan, Manion, \& Morrison, 2007). Metode kualitatif digunakan karena memberikan peluang kepada responden untuk memberikan informasi secara terbuka dan luas. Sementara itu, internet-based research dipilih sebagai pendekatan dalam penelitian ini karena penelitian ini dilaksanakan di masa pandemik virus korona (covid-19) yang sedang merebak di Indonesia, sehingga tidak memungkinkan bagi peneliti untuk bertemu dengan responden secara langsung. Platform yang digunakan dalam penelitian ini yaitu schoology, sebuah management learning system (MLS). Peneliti menggunakan MLS ini karena responden cukup familiar dan punya pengalaman dalam menggunakannya. Penelitian ini dilaksanakan pada semester genap tahun 2019/2020. 
Partisipan dalam penelitian ini yaitu 38 mahasiswa pendidikan guru sekolah dasar (36 perempuan dan 2 laki-laki) dari sebuah institusi pendidikan guru di provinsi Riau, Indonesia. Mahasiswa tersebut merupakan mahasiswa semester 6, dan mereka telah mengambil matakuliah-matakuliah terkait matematika yaitu konsep dasar matematika SD I, konsep dasar matematika SD II, pendidikan matematika SD kelas rendah, pendidikan matematika SD kelas tinggi, dan statistika pendidikan. Sementara itu, pada saat penelitian, mahasiswa tersebut sedang mengambil mata kuliah kapita selekta matematika. Materi pecahan telah mereka pelajari di konsep dasar matematika SD I, dan pembelajaran pecahan dipelajari di pendidikan matematika SD kelas tinggi. Sementara itu, pada mata kuliah kapita selekta matematika, mereka mempelajari teori-teori terkait pembelajaran matematika diantaranya yang telah mereka pelajari yaitu number sense, literasi matematika, problem solving dan problem posing.

Instrumen penelitian ini memuat 4 soal terbuka terkait dengan pecahan dan sejalan dengan teori-teori terkait pembelajaran matematika yang telah mahasiswa pelajari. Setiap soal yang diberikan ke mahasiswa memuat komponen praxeology yaitu menuntun mereka untuk menyajikan soal, teknik untuk menyelesaikan soal tersebut, serta blok teoretikal. Soal tersebut diadabtasi dan dikembangkan dari penelitian sebelumnya (Putra, 2016, 2018, 2019a). Keempat soal tersebut disajikan sebagai berikut:

1. Buatlah sebuah soal number sense tentang pecahan! Tuliskan kemungkinan strategistrategi siswa dalam menjawab soal tersebut! Jelaskan alasan siswa untuk setiap kemungkinan jawaban yang diberikan!

2. Buatlah sebuah soal pemecahan masalah tentang pecahan! Tuliskan kemungkinankemungkinan cara penyelesaian yang akan digunakan siswa dalam menjawab soal tersebut! Jelaskan alasan siswa untuk setiap cara yang mereka pilih!

3. Buatlah sebuah soal literasi matematika tentang operasi pecahan! Tuliskan kemungkinan-kemungkinan cara penyelesaian yang akan digunakan siswa dalam menjawab soal tersebut! Jelaskan alasan siswa untuk setiap cara yang mereka pilih!

4. Buatlah sebuah soal kontekstual pembagian pecahan dengan pecahan! Tuliskan semua cara penyelesaian untuk soal tersebut! Berikan alasan anda atas cara-cara penyelesaian tersebut!

Ke-empat soal tersebut diberikan ke mahasiswa secara random, dan waktu untuk menyelesaikan soal tersebut yaitu 75 menit.

Langkah pertama dalam menganalisa data yaitu mengevaluasi setiap soal yang diberikan oleh mahasiswa. Soal-soal tersebut dikelompokkan berdasarkan ketepatan soal. Soal-soal yang benar dan sesuai dengan yang diminta pada pertanyaan selanjutnya 
dikategorikan berdasarkan tipe soal (type of task). Langkah kedua peneliti menganalisa teknik yang diberikan mahasiswa terhadap tipe soal yang benar tersebut, dan mengkategorikannya sesuai dengan karakter teknik yang diberikan. Selanjutnya, peneliti menganalisis logos, khususnya teknologi untuk setiap teknik yang disajikan. Sementara itu, time triangulation digunakan dalam penelitian ini yaitu peneliti mengkategorikan hasil jawaban mahasiswa dari beberapa waktu yang berbeda untuk melihat stabilitas data yang diamati dari waktu ke waktu.

\section{Hasil Penelitian}

Pengetahuan didaktik calon guru sekolah dasar jika dilihat dari kemampuan mereka dalam mengajukan soal-soal tentang pecahan disajikan pada tabel 1. Secara keseluruhan, calon guru sekolah dasar dalam penelitian ini memiliki kemampuan yang rendah dalam mengkonstruksi soal tentang pecahan, terutama pada kemampuan merancang soal kontekstual terkait pembagian pecahan dengan pecahan. Dalam hal ini, hanya 5 mahasiswa yang mampu menkonstruksinya dengan benar, terutama jika dibandingkan dengan aspek-aspek lainnya.

Tabel 1. Pengetahuan didaktik calon guru sekolah dasar secara umum

\begin{tabular}{clc}
\hline No. & $\begin{array}{l}\text { Soal didaktik yang diberikan kepada calon guru } \\
\text { sekolah dasar }\end{array}$ & $\begin{array}{c}\text { Persentase } \\
\text { jawaban benar }\end{array}$ \\
\hline 1 & Merancang soal number sense tentang pecahan & $71,05 \%$ \\
\hline 2 & Merancang soal pemecahan masalah tentang pecahan & $65,79 \%$ \\
\hline 3 & $\begin{array}{l}\text { Merancang soal literasi matematika tentang operasi } \\
\text { pecahan }\end{array}$ & $60.53 \%$ \\
\hline 4 & $\begin{array}{l}\text { Merancang soal kontekstual pembagian pecahan dengan } \\
\text { pecahan }\end{array}$ & $13,16 \%$ \\
\hline & Rata-rata persentase keseluruhan & $52,63 \%$ \\
\hline
\end{tabular}

Selanjutnya, peneliti menyajikan praxeology didaktika calon guru sekolah dasar untuk setiap aspek pengetahuan yang mereka sajikan. Tujuannya yaitu untuk melihat lebih rinci sejauh mana pengetahuan didaktik calon guru sekolah dasar tentang pecahan.

\section{Praxeology didaktik calon guru sekolah dasar tentang pecahan berbasis number sense}

Calon guru sekolah dasar dalam studi ini memiliki kemampuan yang baik dalam mengkonstruksi soal-soal pecahan menggunakan pendekatan number sense. Lebih dari $70 \%$ calon guru sekolah dasar memberikan konstruksi pecahan yang benar terkait dengan number sense. Tabel 2 menyajikan tipe soal yang mereka ajukan dalam mengkonstruksi pecahan menggunakan number sense, beserta dengan teknik yang sesuai untuk setiap soal tersebut juga teknologi untuk menjustifikasi teknik, dan kemungkinan teoritisnya (logos). 
Tabel 2. Praxeology didaktik calon guru tentang pecahan berbasis number sense

\begin{tabular}{|c|c|c|c|c|}
\hline No. & Tipe Soal & $N$ & Teknik & Logos \\
\hline 1 & $\begin{array}{l}\text { Pecahan sebagai bagian } \\
\text { dari keseluruhan }\end{array}$ & 3 & $\begin{array}{l}\text { Membuat } \\
\text { gambar/diagram }\end{array}$ & $\begin{array}{l}\text { Memudahkan siswa } \\
\text { memahami konsep }\end{array}$ \\
\hline 2 & $\begin{array}{l}\text { Pecahan senilai/ Pecahan } \\
\text { equivalen }\end{array}$ & 1 & 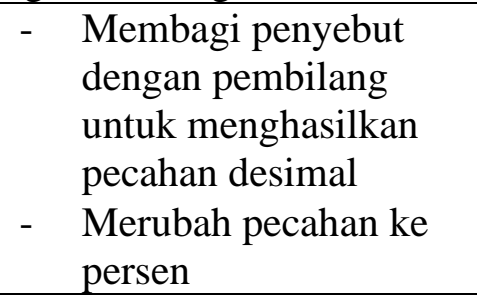 & $\begin{array}{l}\text { Kesamaan } \\
\text { bermacam-macam } \\
\text { representasi pecahan } \\
\text { dan number sense }\end{array}$ \\
\hline \multirow[t]{2}{*}{3} & Perbandingan pecahan & 7 & $\begin{array}{l}\text { - } \begin{array}{l}\text { Membuat diagram/ } \\
\text { gambar }\end{array} \\
\text { - } \begin{array}{l}\text { Menyamakan } \\
\text { penyebut }\end{array}\end{array}$ & $\begin{array}{l}\text { Diagram digunakan } \\
\text { untuk pecahan yang } \\
\text { sederhana } \\
\text { Praktis untuk } \\
\text { pecahan yang } \\
\text { berukuran besar }\end{array}$ \\
\hline & & & $\begin{array}{ll}\text { - } & \text { Merubah ke pecahan } \\
\text { desimal } \\
\text { - } \\
\text { Membandingkan sisa } \\
\text { pecahan }\end{array}$ & $\begin{array}{l}\text { Sisa pecahan yang } \\
\text { lebih kecil memiliki } \\
\text { ukuran yang lebih } \\
\text { besar }\end{array}$ \\
\hline \multirow[t]{2}{*}{4} & Perbandingan desimal & 1 & $\begin{array}{l}\text { - Merubah ke bentuk } \\
\text { pecahan dan } \\
\text { menyamakan penyebut }\end{array}$ & $\begin{array}{l}\text { Menggunakan } \\
\text { benchmark } \\
\text { (membandingkan } \\
\text { dengan pecahan yg } \\
\text { familiar seperti 1/2) }\end{array}$ \\
\hline & & & $\begin{array}{l}\text { - Merubah ke bilangan } \\
\text { bulat }\end{array}$ & \\
\hline \multirow[t]{2}{*}{5} & Penjumlahan pecahan & 3 & $\begin{array}{l}\text { Menggunakan } \\
\text { representasi diagram } \\
\text { seperti representasi } \\
\text { pizza }\end{array}$ & \\
\hline & & & Algoritma standar & $\begin{array}{l}\text { Teknik yang mudah } \\
\text { dipahami siswa }\end{array}$ \\
\hline 6 & $\begin{array}{l}\text { Penjumlahan dan } \\
\text { pengurangan pecahan }\end{array}$ & 1 & Algoritma standar & \\
\hline 7 & Perkalian pecahan & 8 & $\begin{array}{l}\text { Merubah pecahan ke } \\
\text { bentuk yang lebih } \\
\text { sederhana dengan mengali } \\
\text { atau membagi bilangan }\end{array}$ & $\begin{array}{l}\text { Menggunnakan sifat } \\
\text { bilangan, } \\
\text { menghindari } \\
\text { merubah pecahan ke } \\
\text { desimal, dan number } \\
\text { sense }\end{array}$ \\
\hline \multirow[t]{3}{*}{8} & Pembagian pecahan & 3 & Algoritma standar & $\begin{array}{l}\text { Hanya ini cara yang } \\
\text { diketahui siswa }\end{array}$ \\
\hline & & & Merubah ke desimal & $\begin{array}{l}\text { Kesulitan melakukan } \\
\text { operasi pembagian } \\
\text { pecahan }\end{array}$ \\
\hline & & & Menggunakan diagram & $\begin{array}{l}\text { Kreatifitas dan } \\
\text { number sense }\end{array}$ \\
\hline
\end{tabular}


Dari tabel 2, kita dapat melihat perkalian pecahan dan perbandingan pecahan merupakan tipe soal yang paling banyak digunakan oleh calon guru dalam mengkonstruksi pecahan berbasis number sense. Sedangkan pecahan senilai, perbandingan desimal, serta penjumlahan dan penguran pecahan merupakan tipe soal yang paling sedikit mereka gunakan dalam mengkostrusi pecahan. Beberapa soal yang mereka berikan diikuti dengan beberapa alternatif teknik untuk menyelesaikannya. Algoritma standar merupakan teknik yang umum mereka ajukan, namun beberapa teknik berbasis number sense juga disajikan, seperti teknik untuk menyelesaiak soal terkait perkalian pecahan. Sementara itu, teknik-teknik tersebut sebagian besar didukung oleh argument atau justifikasi yang berkaitan dengan number sense. Sehingga, kita dapat berargumen bahwa number sense menjadi didaktik teori untuk mendukung beragam teknologi yang mereka utarakan. Sebagai contoh konstruksi praxeology didaktik berdasarkan perkalian pecahan disajikan oleh responden M9 (Gambar 1).

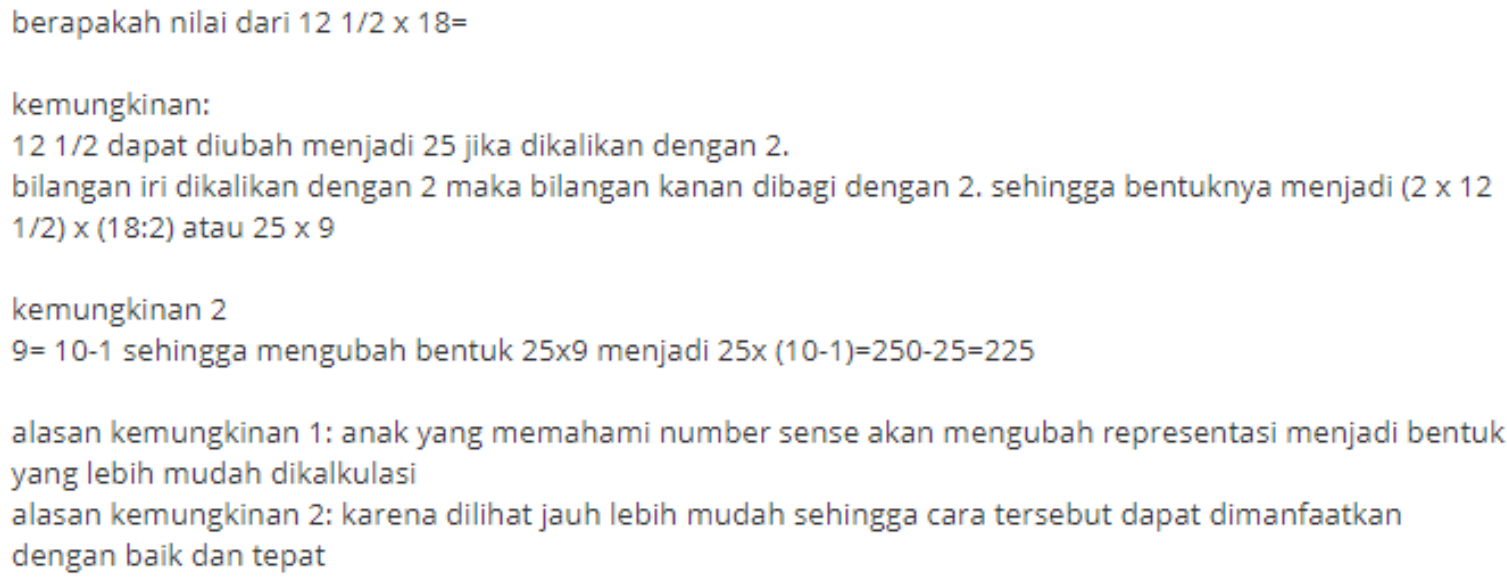

Gambar 1. Jawaban M9 terkait dengan soal didaktik tentang number sense

Soal yang diajukan oleh M9 yaitu menentukan nilai perkalian pecahan dengan bilangan bulat (Gambar 1). Dari soal tersebut, M9 mengajukan sebuah teknik berdasarkan number sense yaitu dengan mengalikan $12 \frac{1}{2}$ dengan 2 (invers $\frac{1}{2}$ ) untuk merubah bilangan tersebut menjadi bilangan bulat, dan konsekwensinya pengali harus dibagi dengan 2. Sementara itu, pada saat menjastifikasi teknik tersebut, M9 menyatakan bahwa pemahaman siswa tentang number sense dapat membantu mereka dalam melakukan operasi perkalian pecahan dengan cara lebih mudah. Sehingga, number sense dapat dikatakan sebagai dimensi teori yang digunakan oleh M9. 


\section{Praxeology didaktik calon guru sekolah dasar tentang pecahan berbasis pemecahan masalah}

Calon guru sekolah dasar memiliki kemampuan yang cukup baik dalam mengkonstruksi soal-soal pecahan menggunakan pendekatan pemecahan masalah. Lebih dari $65 \%$ calon guru sekolah dasar memberikan konstruksi pecahan yang benar terkait dengan pemecahan masalah. Namun, soal-soal pecahan yang dikonstruksi oleh calon guru sekolah dasar menggunakan pendekatan routine problem solving yaitu soal-soal kontekstual terkait dengan kehidupan sehari-hari siswa yang sederhana. Tabel 3 menampilkan tipe soal yang mereka ajukan dalam mengkonstruksi pecahan berbasis pemecahan masalah, diikuti dengan teknik, juga teknologi untuk menjustifikasi teknik, dan kemungkinan teoritisnya (logos).

Tabel 3. Praxeology didaktik calon guru tentang pecahan berbasis pemecahan masalah

\begin{tabular}{|c|c|c|c|c|}
\hline No. & Tipe Soal & $N$ & Teknik & Logos \\
\hline 1 & $\begin{array}{l}\text { Pecahan senilai/ Pecahan } \\
\text { equivalen }\end{array}$ & 2 & $\begin{array}{l}\text { Pemisalan pecahan } \\
\text { dengan variabel } a \text { dan } b \text {, } \\
\text { kemudian membuat } \\
\text { persamaan untuk } \\
\text { diselesaikan }\end{array}$ & $\begin{array}{l}\text { Mempertimbangkan } \\
\text { segala kemungkinan }\end{array}$ \\
\hline 2 & Perbandingan pecahan & 1 & Menggunakan rasio & $\begin{array}{l}\text { Menggunakan } \\
\text { kemungkinan }\end{array}$ \\
\hline 3 & Penjumlahan pecahan & 4 & $\begin{array}{ll}\text { - } & \begin{array}{l}\text { Menggunakan objek } \\
\text { konkret berupa kue }\end{array} \\
\text { - } & \begin{array}{l}\text { Membuat diagram } \\
\text { lingkaran sebagai } \\
\text { representasi objek } \\
\text { konkret }\end{array} \\
\text { - } & \text { Algoritma standar } \\
& \\
\text { - Merubah pecahan ke } \\
\text { desimal kemudian } \\
\text { melakukan operasi } \\
\text { penjumlahan desimal }\end{array}$ & $\begin{array}{l}\text { Media membantu } \\
\text { siswa lebih paham } \\
\text { dan efisien }\end{array}$ \\
\hline 34 & $\begin{array}{l}\text { Penjumlahan dan } \\
\text { pengurangan pecahan }\end{array}$ & 5 & $\begin{array}{l}\text { Memisahkan satuan } \\
\text { dengan pecahan, lalu } \\
\text { melakukan algoritma } \\
\text { standar }\end{array}$ & $\begin{array}{l}\text { Memudahkan dalam } \\
\text { penyelesaian }\end{array}$ \\
\hline 5 & $\begin{array}{l}\text { Pengurangan dan } \\
\text { perkalian pecahan }\end{array}$ & 2 & $\begin{array}{ll}- & \text { Algoritma standar } \\
\text { - } & \text { Mengunakan rumus } \\
& \text { luas area sebagai } \\
\text { perkalian pecahan }\end{array}$ & Rumus \\
\hline 6 & $\begin{array}{l}\text { Penjumlahan dan } \\
\text { perkalian pecahan }\end{array}$ & 1 & $\begin{array}{l}\text { Merubah pecahan desimal } \\
\text { ke pecahan biasa, dan } \\
\text { algoritma standar }\end{array}$ & $\begin{array}{l}\text { Aturan penjumlahan } \\
\text { dan perkalian } \\
\text { bilangan }\end{array}$ \\
\hline
\end{tabular}




\begin{tabular}{|c|c|c|c|c|}
\hline No. & Tipe Soal & $N$ & Teknik & Logos \\
\hline 7 & Perkalian pecahan & 2 & $\begin{array}{l}\text { Membuat langkah- } \\
\text { langkah penyelesaian dan } \\
\text { menjalankan algoritma } \\
\text { perkalian }\end{array}$ & $\begin{array}{l}\text { Lebih mudah dengan } \\
\text { cara menguraikan } \\
\text { langkah-langkah } \\
\text { penyelesaian }\end{array}$ \\
\hline 8 & $\begin{array}{l}\text { Perkalian persen dengan } \\
\text { bilangan bulat }\end{array}$ & 1 & Algoritma standar & $\begin{array}{l}\text { Cara yang diajarkan } \\
\text { guru }\end{array}$ \\
\hline 9 & Pembagian pecahan & 4 & $\begin{array}{ll}\text { - } & \text { Algoritma standar } \\
\text { - } & \text { Menggunakan invers } \\
\text { pembagian sebagai } \\
\text { kebalikan perkalian } \\
\text { bilangan }\end{array}$ & $\begin{array}{ll}\text { - } & \text { Mudah dipahami } \\
& \text { siswa } \\
\text { - } & \text { Mudah dan } \\
& \text { sederhana }\end{array}$ \\
\hline 10 & Pola bilangan & 1 & $\begin{array}{l}\text { Menjumlahkan dua } \\
\text { bilangan sebelumnya }\end{array}$ & \\
\hline 11 & Rasio & 1 & $\begin{array}{l}\text { Menggunakan rasio } 2 \\
\text { bilangan }\end{array}$ & \\
\hline 12 & Aritmatika social & 2 & $\begin{array}{l}\text { Menggunakan } \\
\text { perbandingan }\end{array}$ & \\
\hline
\end{tabular}

Soal-soal pemecahan masalah yang diajukan oleh calon guru sekolah dasar pada umumnya dikonstruksi berdasarkan domain operasi pecahan dengan beberapa tipe soal berbeda yaitu penjumlahan, pengurangan, perkalian dan pembagian pecahan (Tabel 3). Algoritma standar masih menjadi teknik yang dominan yang diajukan oleh calon guru sekolah dasar untuk menyelesaikan soal-soal yang disajikan. Namun, beberapa teknik berbasis pemecahan masalah dan penalaran juga mereka ajukan seperti menggunakan representasi objek konkret dan diagram untuk menyelesaikan soal penjumlahan pecahan. Sementara itu, keyakinan calon guru sekolah dasar bahwa menggunakan algoritma lebih mudah, cepat dan sederhana dalam menyelesaikan soal-soal merupakan teknologi yang mereka gunakan untuk menjustifikasi teknik terkait dengan algoritma standar. Namun, beberapa calon guru juga berargumen berdasarkan strategi-strategi yang ada dalam pemecahan masalah seperti mengunakan kemungkinan dan mengikuti langkah-langkah penyelesaian. Sebagai contoh konstruksi praxeology didaktik, berikut ini kami sajikan hasil kerja responden M11.

Soal yang diajukan oleh M11 merupakan contoh soal pemecahan masalah non routine dan merupakan tipe soal tentang pecahan senilai (Gambar 2). Dari soal tersebut, M11 mengajukan sebuah teknik yaitu pemisalan pecahan dengan variabel $a$ dan $b$, kemudian membuat persamaan untuk diselesaikan. Sementara itu, teknologi yang diajukan berdasarkan atas pemahamanya tentang strategi-strategi pemecahan masalah yaitu mempertimbangkan segala kemungkinan. 


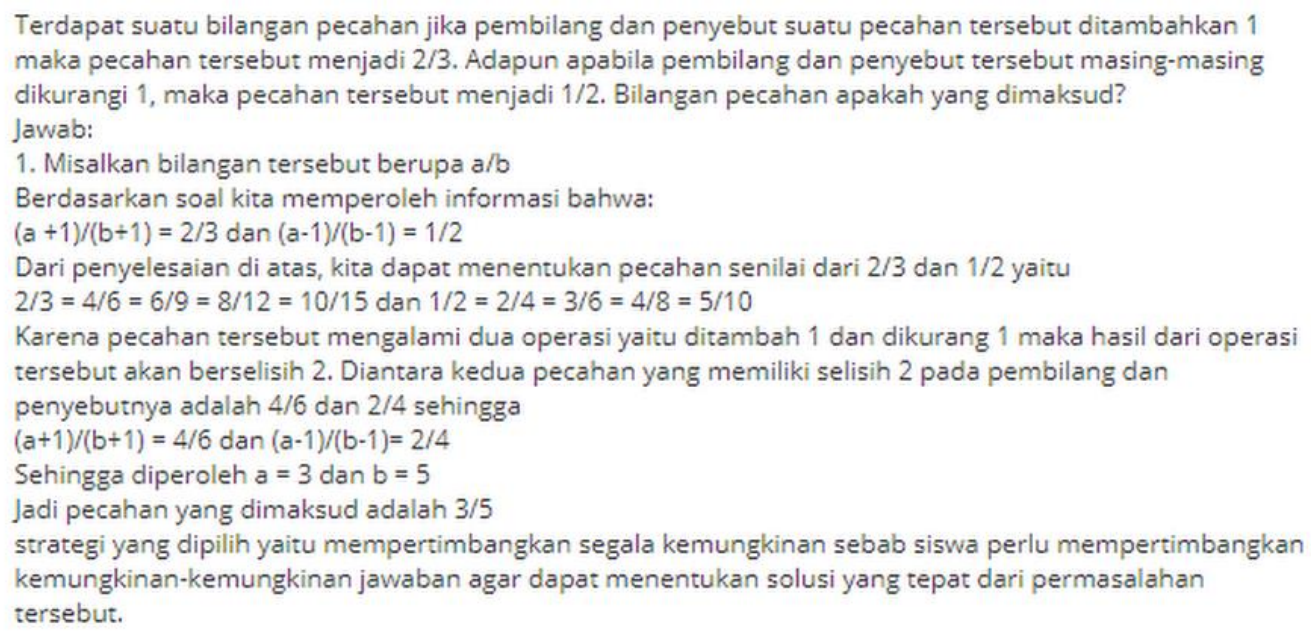

Gambar 2. Jawaban M11 terkait dengan soal didaktik tentang pemecahan masalah

\section{Praxeology didaktik calon guru sekolah dasar tentang operasi pecahan berbasis literasi matematika}

Pengetahuan calon guru sekolah dasar terkait dengan konstruksi soal-soal pecahan berdasarkan literasi matematika hampir sama dengan pemecahan masalah. Hanya $60 \%$ dari mereka yang mampu memberikan konstruksi pecahan yang tepat terkait literasi matematika. Pada umumnya soal pecahan berbasis literasi matematika yang dikonstruksi menggunakan konteks personal, dan hanya ada 3 soal yang menggunakan konteks sosial dan 1 soal terkait konteks pekerjaan. Tabel 4 berikut ini disajikan tipe soal yang mereka ajukan dalam mengkonstruksi pecahan berbasis literasi matematika, diikuti dengan teknik, juga teknologi untuk menjustifikasi teknik, dan kemungkinan teoritisnya (logos).

Tabel 4. Praxeology didaktik calon guru tentang pecahan berbasis literasi matematika

\begin{tabular}{|c|c|c|c|c|}
\hline No. & Tipe Soal & $N$ & Teknik & $\log O$ \\
\hline 1 & $\begin{array}{l}\text { Mengurutkan dan } \\
\text { menjumlahkan pecahan }\end{array}$ & 2 & $\begin{array}{ll}\text { - } & \text { Merubah ke pecahan } \\
\text { lalu mengurutkan dan } \\
\text { menjumlahkan } \\
\text { bilangan pecahan } \\
\text { - } \\
\text { Merubah ke desimal } \\
\text { lalu mengurutkan dan } \\
\text { menjumlahkan } \\
\text { bilangan desimal } \\
\text { - } & \text { Algoritma standar } \\
\end{array}$ & \\
\hline 2 & Penjumlahan pecahan & 2 & Algoritma standar & \\
\hline 3 & $\begin{array}{l}\text { Penjumlahan dan } \\
\text { pengurangan pecahan }\end{array}$ & 4 & $\begin{array}{l}\text { Memisahkan antara } \\
\text { bilangan bulat dan } \\
\text { pecahan, kemudian } \\
\text { melakukan algoritma } \\
\text { standar } \\
\text { - } \quad \text { Merubah ke desimal }\end{array}$ & Number sense \\
\hline
\end{tabular}




\begin{tabular}{|c|c|c|c|c|}
\hline No. & Tipe Soal & $N$ & Teknik & Logos \\
\hline & & & - $\quad$ Algoritma standar & \\
\hline \multirow[t]{3}{*}{4} & Pengurangan pecahan & 10 & $\begin{array}{l}\text { Membuat } \\
\text { gambar/diagram }\end{array}$ & $\begin{array}{l}\text { Representasi dari } \\
\text { abstrak ke konkret, } \\
\text { Media } \\
\text { mempermudah } \\
\text { dalam belajar }\end{array}$ \\
\hline & & & $\begin{array}{l}\text { - } \begin{array}{l}\text { Menggunakan benda } \\
\text { konkret }\end{array}\end{array}$ & $\begin{array}{l}\text { Lebih mudah } \\
\text { dipahami siswa dan } \\
\text { belajar dari } \\
\text { kehidupan nyata }\end{array}$ \\
\hline & & & - Algoritma standar & Sederhana dan cepat \\
\hline 5 & $\begin{array}{l}\text { Pengurangan dan } \\
\text { perkalian pecahan }\end{array}$ & 2 & Algoritma standar & \\
\hline 6 & $\begin{array}{l}\text { Pengurangan pecahan } \\
\text { dan perbandingan }\end{array}$ & 1 & $\begin{array}{l}\text { Algoritma standar dan } \\
\text { rasio }\end{array}$ & \\
\hline 7 & Pembagian pecahan & 2 & $\begin{array}{ll}\text { - } & \text { Algoritma standar } \\
\text { - } & \text { Penalaran sederhana } \\
\end{array}$ & Number sense \\
\hline
\end{tabular}

Dari tabel 4, kita dapat melihat bahwa soal-soal pecahan berbasis literasi matematika pada umunya dikonstruksi berdasarkan domain operasi pecahan dengan tipe soal yang dominan yaitu pengurangan pecahan. Pada umumnya, mereka memgajukan algoritma standar untuk menyelesaikan soal-soal yang ada. Sementara itu, banyak dari calon guru yang tidak memberikan justifikasi terhadap teknik yang mereka sampaikan. Namun, teknologi yang umum disampaikan untuk menjustifikasi teknik berdasarkan algoritma standar yaitu karena teknik ini mudah dan sederhana bagi siswa untuk digunakan. Number sense juga digunakan sebagai teori untuk menjelaskan teknik-teknik selain teknik algoritma standar. Sebagai contoh konstruksi praxeology didaktik, berikut ini kami sajikan hasil kerja responden M1.



Gambar 3. Jawaban M1 terkait dengan soal didaktik tentang literasi matematika 
Soal yang diajukan oleh M1 merupakan contoh soal literasi matematika sederhana tentang pengurangan pecahan dengan konteks personal (Gambar 3). Dari soal tersebut, M1 mengajukan 3 teknik yang dapat digunakan siswa untuk menyelesaikan soal tersebut. Dua teknik berdasarkan informal strategi yaitu dengan mengunakan objek konkret dan diagram, sedangkan 1 teknik berdasarkan algoritma standar. Namun, M1 tidak menguraikan secara lengkap dari masing-masing teknik tersebut untuk menyelesaikan soal yang ada. Untuk setiap teknik, M1 mengutaraakan teknologi dan salah satunya yaitu terkait pentingnya konkritisasi dari suatu situasi yang abstrak sehingga siswa mampu menalarkan situasi yang ada.

\section{Praxeology didaktik calon guru sekolah dasar tentang pembagian pecahan berbasis problem posing}

Pengetahuan calon guru sekolah dasar terkait dengan konstruksi soal kontekstual pembagian pecahan dengan pecahan sangat rendah. Hanya $13 \%$ dari mereka yang mampu mengajukan soal yang tepat tentang operasi ini. Pada umumnya soal pembagian pecahan dengan pecahan dikonstruksi berdasarkan konsep partitive reasoning. Tabel 5 berikut ini disajikan tipe soal yang mereka ajukan dalam mengkonstruksi pembagian pecahan dengan pecahan, diikuti dengan teknik, juga teknologi untuk menjustifikasi teknik, dan kemungkinan teoritisnya $(\log o s)$.

Tabel 5. Praxeology didaktik calon guru tentang pembagian pecahan dengan pecahan

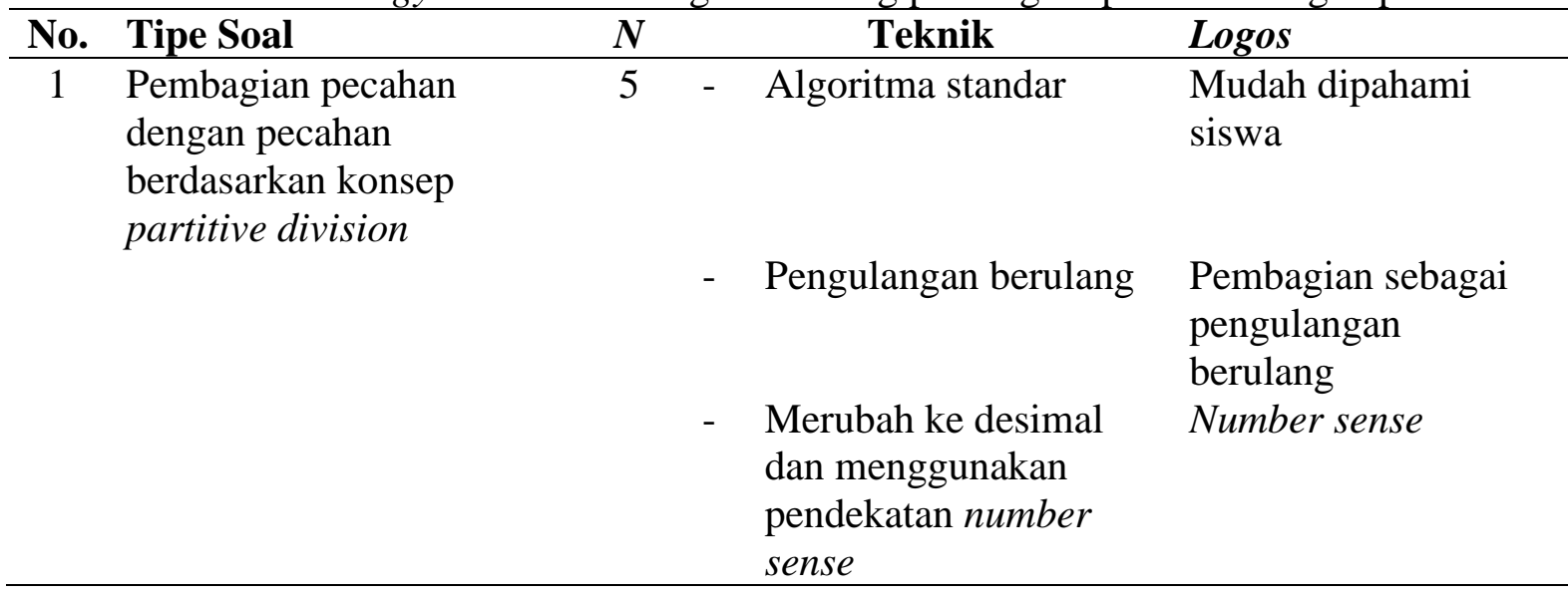

Soal kontekstual tentang pembagian pecahan dengan pecahan yang dikonstruksi oleh calon guru semuanya berdasarkan konsep partitive division. Sementara itu, terdapat 3 teknik berbeda untuk menyelesaikan soal tersebut namun 4 dari 5 calon guru sekolah dasar hanya mengajukan 1 teknik yaitu algoritma standar. Argumen yang mereka sampaikan yaitu teknik ini mudah dipahami oleh siswa. Sementara itu, 1 calon guru yang lain mengajukan ke 3 
alternatif teknik yang ada beserta dengan technologi untuk menjustifikasinya. Pada gambar 4 berikut ini kami sajikan konstruksi praxeology didaktika dari M33.

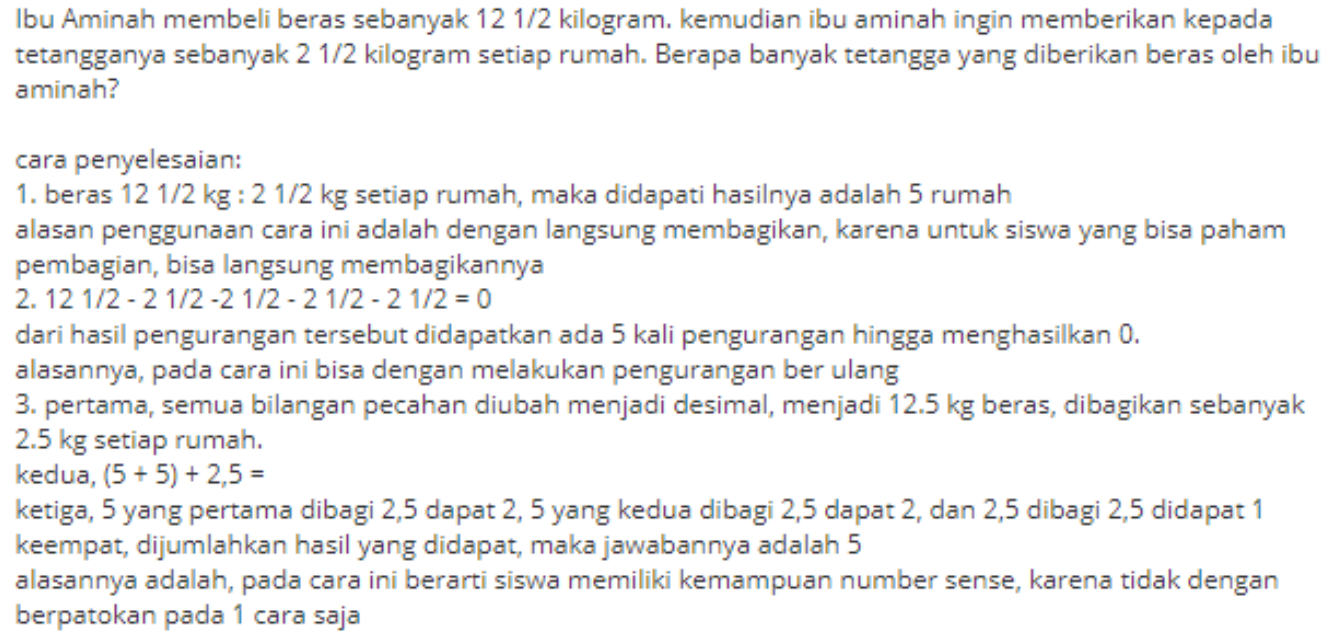

Gambar 4. Jawaban M33 terkait dengan soal didaktik tentang problem posing

Soal yang diajukan oleh M33 menggunakan konteks pembagian beras ke dalam beberap bagian dengan ukuran yang lebih kecil (Gambar 4). Pecahan yang digunakan yaitu pecahan campuran dengan angka yang dapat dipahami oleh siswa dengan mudah. Ketiga teknik yang disajikan cukup jelas, namun teknik pertama, M33 tidak memberikan penjabaran bagaiaman siswa yang telah paham pembagian bisa melakukan pembagian $12 \frac{1}{2} \div 2 \frac{1}{2}$. Teknik kedua berdasarkan pada pengurangan berulang, dan teknik ini seyogyanya bisa diterapkan siswa karean pecahan yang digunakan sederhana dan pembagian tidak menghasilkan sisa. Begitu juga dengan teknik ke 3 yaitu dengan merubah ke pecahan desimal dan pengetahuan siswa tentang number sense menjadi teori penting untuk menjustifikasinya.

\section{Pembahasan}

Kemampuan guru menyajikan soal-soal matematika yang tepat didepan kelas dapat menentukan arah dan keberhasilan proses pembelajaran yang dialami oleh siswa. Namun, menyajikan sebuah soal yang baik, dalam hal ini terkait dengan kesusaian konteks dan konten matematika, perlu latihan dan pengalaman yang panjang bagi guru (Putra, 2018; Siegler \& Lortie-Forgues, 2017) .

Peneliti menfokuskan pada kemampuan calon guru sekolah dasar dalam mengkonstruksi soal-soal tentang pecahan dari 4 teori di pendidikan matematika, number sense, pemecahan masalah, literasi matematika, dan problem posing. Hasil studi ini secara umum menunjukkan bahwa pengetahuan calon guru sekolah dasar dalam mengkonstruksi 
soal-soal kontekstual tentang pecahan masih rendah. Ini bermakna bahwa konsep pecahan merupakan konsep yang sulit bagi mereka untuk diajarkan di sekolah dasar. Hasil studi ini sejalan dengan hasil studi yang dilakukan oleh peneliti-peneliti sebelumnya (Austin, Carbone, \& Webb, 2011; Dixon et al., 2014; Putra, 2016, 2019a; Toluk-Uçar, 2009). Putra (2019) misalnya yang menemukan bahwa hanya sekitar $25 \%$ guru sekolah dasar yang mengikuti pendidikan guru mampu menyajikan soal kontekstual perkalian pecahan dengan bilangan bulat. Padahal mereka merupakan guru-guru yang sehari-harinya menghabiskan waktu bersama siswa dan sebagian dari mereka juga telah mengajarkan tentang pecahan di sekolah. Sementara itu (Dixon et al., 2014) menemukan bahwa calon guru kesulitan dalam mendefenisikan keseluruhan yang berdampat terhadap kesulitan mereka dalam membuat soal kontekstual yang tepat tentang pengurangan pecahan.

Berbeda dari studi-studi sebelumnya (Depaepe et al., 2015; Newton, 2008; van Steenbrugge et al., 2014), studi ini mempelajari pengetahuan guru tidak hanya pada aspek praktis tetapi juga pada aspek teoritis terkait dengan konsep pecahan. Calon guru diminta untuk memberikan penjelasan terhadap teknik yang mereka ajukan dalam setiap soal kontekstual yang mereka ajukan. Pada umumnya calon guru sekolah dasar mengajukan soalsoal kontekstual yang sederhana, seperti penjumlahan dan pengurangan pecahan, dan umumnya mereka menyajikan algoritma standar sebagai teknik untuk digunakan oleh siswa, dengan alasan teknik ini lebih cepat dan mudah dipahami siswa. Namun, pendapat-pendapat ini bertentangan dengan teori-teori yang berkembang di pendidikan matematika, seperti Pendidikan Matematika Realistik (Freudenthal, 1991) dan Teori Situasi Didaktik (Brousseau, 2002). Algoritma standar dipandang sebagai teknik yang kurang bermakna bagi siswa, dan teknik ini bersifat hafalan sehingga ketika siswa lupa maka mereka tidak dapat menyelesaikan persoalan yang diberikan. Hal ini bertentang dengan matematika sebagai aktivitas manusia dan matematika dipahami melalui proses matematisasi dari konkret ke abstrak. Walaupun demikian, beberapa calon guru sekolah dasar menyadari pentingnya representasi dari abstrak ke konkret dan meedia dalam pembelajaran guna mempermudah siswa dalam memahami konsep pecahan.

Dari empat aspek yang diujikan, maka pengetahuan calon guru sekolah dasar dalam mengkonstruksi soal kontekstual tentang pembagian pecahan dengan pecahan yang paling rendah. Hasil ini tentu tidak mengejutkan karena dari studi-studi sebelumnya (Ma, 1999; Putra, 2016) juga menunjukkan hasil yang sama. Ma, (1999) misalnya menemukan bahwa hampir sebagian besar guru sekolah dasar di Amerika Serikat tidak mampu menjelaskan makna pembagian pecahan dan juga mengkonstruksi situasi pembelajaran terkait konsep 
tersebut. Rendahnya kemampuan mereka dalam mengkonstruksi soal kontekstual tentang pembagian pecahan dengan pecahan karena mereka kurang memahami makna pembagian pecahan itu sendiri. Sebagaimana hasil studi Alenazi (2017) bahwa dari beragam interpretasi pembagian pecahan, konsep pengukuran dan rata-rata seringkali tidak dapat dihubungkan oleh calon guru ke pembagian pecahan. Padahal konsep pengukuran ataupun partitive division merupakan konsep yang sederhana dan mudah dipahami siswa untuk menjelaskan pembagian pecahan. Sementara itu, kesulitan guru dalam mengerjakan soal terkait pembagian pecahan karena kesulitan mereka untuk merubah pandagan mereka dari pembagian bilangan bulat ke pembagian pecahan, dimana Putra (2019b) menyebutnya dengan istilah praxeological change. Jadi, Pengetahuan didaktika calon guru sekolah dasar sangat ditentukan oleh kemampuan matematika mereka. Mereka yang memiliki pemahaman konseptual atau teoretikal yang baik tentang pecahan mampu merancang soal kontekstual dari berbagai aspek baik number sense, pemecahan masalah, literasi matematika, dan problem possing.

\section{Simpulan}

Pengetahuan calon guru sekolah dasar dalam mengkonstruksi soal kontekstual tentang pecahan secara umum masih rendah, terutama pada aspek pembagian pecahan dengan pecahan. Calon guru cenderung mengajukan soal-soal sederhana, seperti operasi penjumlahan dan pengurangan pecahan, yang diikuti dengan teknik berupa algoritma standar untuk menyelesaikan soal-soal tersebut. Sementara itu aspek teori yang digunakan untuk menjustifikasi teknik yang disampaikan bersifat informal dan tidak sejalan dengan apa yang diungkapkan di teori-teori pendidikan matematika, yaitu algoritma dipandang sebagai teknik mekanisitik yang kurang bermakna bagi siswa. Hasil studi ini berkontribusi terhadap 2 hal yaitu terkait dengan metode dalam menginvestigasi pengetahuan guru tentang pecahan dengan menggunakan teori antropologi didaktik, khususnya praxeology, dan yang kedua terkait pentingnya melihat pengetahuan calon guru dari berbagai persepktif, seperti number sense, pemecahan masalah, literasi matematika, dan problem posing. Namun, penelitian ini masih banyak kekurangan dan keterbatasannya terutama dari subjek yang digunakan yang terbatas pada satu institusi pendidikan guru. Sementara itu, metode pengumpulan data yang hanya menggunakan tes tertulis, secara umum tidak dapat mengungkap lebih dalam aspek logos yang ada dalam pikiran-pikiran calon guru tersebut. Kedepannya, perlu dipertimbangkan untuk melakukan interview kepada calon guru untuk memperoleh gambaran yang lebih jelas. 


\section{Ucapan terimakasih}

Peneliti Mengucapkan terima kasih kepada Lembaga Penelitian dan Pengabdian Masyarakat (LPPM) Universitas Riau atas hibah DIPA UNRI tahun 2020 dengan nomor 778/UN.19.5.1.3/PT.01.03/2020.

\section{Referensi}

Alenazi, A. (2017). Examining middle school pre-service teachers' knowledge of fraction division interpretations. International Journal of Mathematics Education in Science and Technology, 47(5), 696-716. https://doi.org/10.1080/0020739X.2015.1083127.

Austin, P., Carbone, R. E., \& Webb, P. (2011). Prospective primary school teachers' attempts to pose acceptable word problems on the addition of fractions: Some insights from south africa and the united states of america. African Journal of Research in Mathematics, Science and Technology Education, 15(2), 168-178. https://doi.org/10.1080/10288457.2011.10740710.

Bosch, M., \& Gascón, J. (2006). Twenty-five years of the didactic transposition. ICMI Bulletin, 58, 51-65.

Brousseau, G. (2002). Theory of didactical situation. New York: Kluwer Academic Publisher.

Castro-Rodríguez, E., Pitta-Pantazi, D., Rico, L., \& Gómez, P. (2016). Prospective teachers' understanding of the multiplicative part-whole relationship of fraction. Educational Studies in Mathematics, 92(1), 129-146. https://doi.org/10.1007/s10649-015-9673-4.

Charalambous, C. Y., \& Pitta-Pantazi, D. (2007). Drawing on a theoretical model to study students' understandings of fractions. Educational Studies in Mathematics, 64(3), 293316. https://doi.org/10.1007/s10649-006-9036-2.

Chevallard, Y. (2006). Steps towards a new epistemology in mathematics education. In M. Bosch (Ed.), Proceedings of the IV Congress of the European Society for Research in Mathematics Education (pp. 21-30). Grenoble: La Pensée Sauvage.

Cohan, L., Manion, L., \& Morrison, K. (2007). Research methods in education (Sixth Edit). London: Routledge. https://doi.org/10.4324/9780203029053.

Depaepe, F., Torbeyns, J., Vermeersch, N., Janssens, D., Janssen, R., Kelchtermans, G., ... Van Dooren, W. (2015). Teachers' content and pedagogical content knowledge on rational numbers: A comparison of prospective elementary and lower secondary school teachers. Teaching and Teacher Education, 47, 82-92. https://doi.org/10.1016/j.tate.2014.12.009.

Dixon, J. K., Andreasen, J. B., Avila, C. L., Bawatneh, Z., Deichert, D. L., Howse, T. D., \& Turner, M. S. (2014). Redefining the whole: common errors in elementary preservice teachers' self-authored word problems for fraction subtraction. Investigations in Mathematics Learning, 7(1), 1-22. https://doi.org/10.1080/24727466.2014.11790336.

Durmus, S. (2005). Identifying pre-service elementary school teachers' conceptualization levels of rational numbers. Educational Sciences: Theory \& Practice, 5(2), 659-666.

Durrand-Guerrier, V., Winsløw, C., \& Yoshida, H. (2010). A model of mathematics teacher knowledge and a comparative study in Denmark, France and Japan. ANNALES de DIDACTIQUE et de SCIENCES COGNITIVES, 15, 147-172.

Freudenthal, H. (1991). Revisiting mathematics education: China lecturers. Dordrecht: Kluwer Academic Publishers.

Hill, H. C., Rowan, B., \& Ball, D. L. (2005). Effects of teachers' mathematical knowledge for teaching on student achievement. American Educational Research Journal, 42(2), 371406. https://doi.org/10.3102/00028312042002371. 
Johar, R., Patahuddin, S. M., \& Widjaja, W. (2017). Linking pre-service teachers' questioning and students' strategies in solving contextual problems: A case study in Indonesia and the Netherlands. The Mathematics Enthusiast, 14(1-3), 101-128. https://doi.org/10.1242/dmm.009688.

Liu, C., Xin, Z., \& Li, X. (2011). The development of chinese students' understanding of the concept of fractions from fifth to eighth grade. Journal of Mathematics Education, 4(2), 17-34. Retrieved from http://educationforatoz.com/images/Liu_Xin_Li.pdf

Ma, L. (1999). Knowing and teaching elementary mathematics: Teachers' understanding of fundamental mathematics in China and the United States. Mahwah, NJ.: Lawrence Erlbaum Associates.

Newton, K. J. (2008). An extensive analysis of preservice elementary teachers' knowledge of fractions. American Educational Research Journal, 45(4), 1080-1110. https://doi.org/10.3102/0002831208320851.

Putra, Z. H. (2016). Pengetahuan mahasiswa pedidikan guru sekolah dasar dalam merepresentasikan operasi pecahan dengan model persegi panjang. Jurnal Elemen, 2(1), 1-13. https://doi.org/10.29408/jel.v2i1.174.

Putra, Z. H. (2018). A praxeological analysis of pre-service elementary teachers' knowledge of rational numbers. Recherches En Didactique Des Mathematiques, 38(3), 315-364.

Putra, Z. H. (2019a). Elementary teachers' knowledge on fraction multiplication: An anthropological theory of the didactic approach. Journal of Teaching and Learning in Elementary Education, 2(1), 47-52. https://doi.org/10.33578/jtlee.v2i1.6964.

Putra, Z. H. (2019b). Praxeological change and the density of rational numbers: The case of pre-service teachers in Denmark and Indonesia. Eurasia Journal of Mathematics, Science and Technology Education, 15(5). https://doi.org/10.29333/ejmste/105867.

Rasmussen, K. (2016). Lesson study in prospective mathematics teacher education: didactic and paradidactic technology in the post-lesson reflection. Journal of Mathematics Teacher Education, 19(4), 301-324. https://doi.org/10.1007/s10857-015-9299-6.

Siegler, R. S., \& Lortie-Forgues, H. (2017). Hard lessons: Why rational number arithmetic is so difficult for so many people. Current Directions in Psychological Science, 26(4), 346-351. https://doi.org/10.1177/0963721417700129.

Thanheiser, E., Moss, M., Browning, C. A., Garza-kling, G., \& Watanabe, T. (2010). Developing mathematical content knowledge for teaching elementary school mathematics. IUMPST: The Journal, 1, 1-13.

Toluk-Uçar, Z. (2009). Developing pre-service teachers understanding of fractions through problem posing. Teaching and Teacher Education, 25(1), 166-175. https://doi.org/10.1016/j.tate.2008.08.003.

Van Dooren, W., Lehtinen, E., \& Verschaffel, L. (2015). Unraveling the gap between natural and rational numbers. Learning and Instruction, 37, 1-4. https://doi.org/10.1016/j.learninstruc.2015.01.001.

van Steenbrugge, H., Lesage, E., Valcke, M., \& Desoete, A. (2014). Preservice elementary school teachers' knowledge of fractions: A mirror of students' knowledge? Journal of Curriculum Studies, 46(1), 138-161. https://doi.org/10.1080/00220272.2013.839003.

Widjaja, W., Stacey, K., \& Steinle, V. (2008). Misconceptions about density of decimals: Insights from Indonesian pre-service teachers' work. Journal for Science and Mathematics Education in Southeast Asia, 31(2), 117-131.

Wijayanti, D., \& Winsløw, C. (2017). Mathematical practice in textbooks analysis: Praxeological reference models, the case of proportion. Journal of Research in Mathematics Education, 6(3), 307-330. https://doi.org/10.17583/redimat.2017.2078.

Winsløw, C., \& Durand-Guerrier, V. (2007). Education of lower secondary mathematics teachers in Denmark and France. Nordic Studies in Mathematics Education, 12(2), 5-32. 